\title{
Article
}

\section{'Connectivity': Seeking conditions and connections for radical discourses and praxes in health, mental health and social work}

Cox, Pat

Available at http://clok.uclan.ac.uk/2012/

Cox, Pat ORCID: 0000-0003-2565-4564 (2009) 'Connectivity': Seeking conditions and connections for radical discourses and praxes in health, mental health and social work. Social Theory \& Health, 7 (2). pp. 170-186. ISSN 14778211

It is advisable to refer to the publisher's version if you intend to cite from the work. http://dx.doi.org/10.1057/sth.2009.9

For more information about UCLan's research in this area go to http://www.uclan.ac.uk/researchgroups/ and search for <name of research Group>.

For information about Research generally at UCLan please go to http://www.uclan.ac.uk/research/

All outputs in CLoK are protected by Intellectual Property Rights law, including Copyright law. Copyright, IPR and Moral Rights for the works on this site are retained by the individual authors and/or other copyright owners. Terms and conditions for use of this material are defined in the policies page. 
'Connectivity': seeking conditions and connections for radical discourses and praxes in health, mental health and social work.

Pat Cox, Senior Lecturer, School of Social Work, Harrington Building, University of Central Lancashire, Preston, PR1 2HE

Email: pcox2@uclan.ac.uk

Tel: 01772893457 
Abstract. This paper begins with reflections on the development and spread of the ideas, discourse and praxis of radical social work in the 1970s and the cross-fertilisation of these discourses and praxes with discourses and praxes within radical health and mental health initiatives. During these years, for many in the fields of health, mental health and social work, their work and their lives were characterised by active involvement in a range of campaigns focused upon health, mental health and social work issues, together with shared values of more transparent and supportive work with users of health, mental health and social work services and a commitment to greater understanding through social and political theorising.

This analysis is compared with the present where workplace cultures in health and social work emphasise meeting delivery and performance targets. It is argued that workers currently in health, mental health and social work with children and with adults share many similar experiences.

Hegemonic discourses and praxes appear immoveable, but dissatisfaction with the status quo can become a disinhibiting factor. Building from experiences and analysis, exploration is begun into what conditions and connections might be needed now to develop radical discourses and praxes in health, mental health and social work. (200 words).

Keywords: health; mental health; social work; radical discourses and praxis 


\section{Introduction}

It is already established that no work of theory, criticism or research can be considered in isolation from its social and political context, or from the person of its author (Calhoun, 2000; Skeggs, 1997; Walkerdine, 1997). This position is manifest in this paper, which begins with a summary of the memories and work experiences of the author, during the development and spread of the ideas, discourse and praxes of radical social work in the 1970s. In the first part of the paper, the cross-fertilisation of these discourses and praxes with those of radical health and mental health initiatives are explored and analysed. In the second part, current work practices and contexts are interrogated and are seen to compare less favourably. In the third and fourth parts an inquiry is begun into what conditions might be necessary to develop more radical ways of thinking and working; in the final part the possibilities of establishing new connections to improve discourses and praxes, patient, service user and carer relationships and service delivery are discussed.

One of the problems encountered in producing this work is that language is linear, with the result that experiences, events and theoretical understandings are described and analysed sequentially; whereas much of what is outlined occurred and occurs either simultaneously or in overlapping time periods. This paper attempts to impose some order and analysis on past and recent developments in health, mental health and social work which inform our current understandings and practice and which may have significance for future understandings and practice.

\section{Developments in radical discourse and praxis}


The Seebohm Report (1968) and concomitant legislation, the Local Authority Social Services Act (1970) resulted in 1971 in the reorganisation of the separate departments for children and families, for people suffering from mental ill-health and for older people, into all-encompassing ‘social services’ departments. Although much of the language in the Seebohm Report is anathema to us now, one strength of the report was that it emphasised the importance of working to develop the potential within communities. A significant consequence of the post-Seebohm reorganisation was a reduction of in-depth practitioner knowledge and expertise and a loss of existing networks; these two issues will be addressed more fully later in the paper.

The discourse of radical social work proper begins with the production of 'Case Con' by an editorial collective. Case Con was both a publication and a loosely organised movement. Drawing from Marxist and from early second-wave feminist ideas and writings, Case Con advocated alliances with service users (then 'clients'). The rationalization of services and the diminution of specialist knowledge following Seebohm and the Local Authority Social Services Act were criticised in the Case Con Manifesto (reprinted in Bailey and Brake, 1975). Case Con addressed questions of gender and of 'race' and devoted a complete issue to lesbian and gay experiences and concerns.

In the city social services department where the author then worked, a group was established to discuss these ideas and to explore how different forms of practice might be possible, although the statutory setting and social control elements of the work; particularly in the light of developing awareness of child abuse amongst health and social 
work professionals (see Kempe et al, 1962), appeared to present some difficulties.

Following the imperative in the Case Con Manifesto to become active in trades unions, a number of us from that group went on to become active in the trade union NALGO, and in related health, mental health and welfare campaigns.

\section{Influences of feminist thinking and action}

Firestone was one of the earliest of 'Second Wave' western feminists to identify the links between the oppression of women and that of children. Commenting that '....women and children are always mentioned in the same breath...' she notes:

'We must include the oppression of children in any feminist revolution or we will be subject to the same failing of which we have often accused men: of not having gone deep enough in our analysis, of having missed an important sub-stratum of oppression merely because it didn’t concern us.' (Firestone, 1979: 101).

This analysis developed the author's political, as well as personal, views about the multiple oppressions endured by children, young women and young men and the need to advocate for their rights, including their right to protection from harm, trauma and abuse. Like colleagues working with adults suffering from mental illness (Pearson, 1975), the author experienced tensions in practice, struggling to integrate feminist and radical ideas with the imperative to protect children and young people. Wise (1988) later addressed such tensions in integrating feminist forms of practice in child protection social work. It would be a few more years before the links between childhood trauma, including sexual 
abuse, depression and mental ill-health in adults - particularly women - would be more fully understood by the professions of health, mental health and social work: for example, Banyard and Williams (1999); Bifulco and Moran (1998); Briere and Runtz (1986, 1987); Cox (1993); Salter (1988); Wyatt and Powell (1988).

With the spread of feminisms came understanding that 'the personal is political' and the lifelong process of seeing connections between the two began. Summarising several years of feminist thinking and action, Morgan writes:

'If I had to characterise one quality as the genius of feminist thought, culture and action it would be connectivity, and this involves noticing. In its rejection of the static, this capacity is witty and protean... It is therefore a volatile capacity dangerous to every conceivable status quo, because of its insistence on noticing. Such noticing involves both attentiveness and recognition, and is in fact a philosophical and activist technique for being in the world, as well as for changing the world.' (Morgan, 1989: 53).

Both Firestone (1979) and Morgan identified and influenced an approach which is about seeing and understanding connections and the concomitant imperatives to include others and to build alliances first, not last.

\section{Connections and activisms}


Radical ideas about practice and the need for more transparent and supportive relationships with service users and carers initiated by Case Con, found ever wider audiences. Analyses by Bailey and Brake (1975; 1980); Cockburn (1977); Corrigan and Leonard (1978); Simpkin (1979); Wilson (1980) were written, read and then discussed in groups and teams. Amongst health workers, the Radical Statistics Health Group (1976; 1978) critiqued the then government's consultation document (Department of Health and Social Security, 1976). Widgery (1979) critically examined the NHS from within; Doyal and Pennell (1979) analysed health and healthcare provision, drawing from a range of disciplines and from Marxist and feminist analyses; while Ehrenreich and English (1974; 1979) challenged the hegemony of male-centred health discourses and treatment. The first Feminism and Social Work Conference took place at Warwick at this time.

The work and lives of a number of workers in health, mental health and social work during these years were characterised by involvement in a range of activisms and protests; as thinking about different forms of praxis in health, mental health and social work, and a strong sense of 'connectivity' (Morgan, 1989: 53) led to involvement in associated campaigns - for example in the Radical Midwives and Radical Health Visitors’ Groups; Mental Patients’ Union; the National Abortion Campaign; Claimants’ Unions; Tenants Associations; Reclaim the Night and the Anti Nazi League. These campaigns, particularly the first four, drew support from a wide base of healthcare and mental health workers, patients, social workers, service users and carers, committed individuals and community groups. Chesler’s (1973) Women and Madness foregrounded the oppressive treatment of women and the gender issues pervading responses to mental 
illness, as did novels by Sylvia Plath (The Bell Jar) and Marge Piercy's Woman on the Edge of Time (1976). Brown's analyses (1973; 1974) of therapy with the strapline 'Therapy means change, not adjustment' and Doris Lessing’s The Golden Notebook (reprinted during the 1970s) challenged misunderstandings about the causes and nature of mental ill-health, showing that psychological therapy was often used to make people 'fit in’ to society rather than challenging or resisting the status quo.

As Firestone (1979) had observed, what happened to others everywhere as well as oneself, mattered. There appeared to be a great confluence of ideas and almost limitless opportunities for thinking about, discussing and actualising change in health, mental health settings, together with individual and shared commitment to greater understanding of relevant social and political theorising about health and welfare. The journal Ideology and Consciousness (later I \& C) unfolded theoretical ideas and analyses and debates about theory (Adlam et al, 1977-1982). Papers in this journal and in the first edition of Changing the Subject (Henriques et al, 1984) were at the forefront of developing and bringing critical and feminist psychology to wider audiences. From the vantage point of the present, the author characterises the experiences of this period as closely resembling Mannheim’s 'generation' (1952: 307) as actuality - many shared these formative experiences, although individual responses to them varied.

These times of analyses and activisms meant that professionals working with those suffering from poor physical health; from mental illness and those working with children and families were well-placed to recognise the potential impact on many patients and 
service users as the Conservative government began rolling back both free healthcare and the welfare state in response to economic crises (Parton, 1996). Imperfect as the NHS and Social Services were, oppressive as they both could be, workers in these settings knew that for some patients, service users and their carers, they offered necessary resources, support, treatment. There were local meetings about changes to benefits and other welfare state provision and the 'leakage' of ration books or vouchers from the DHSS main benefit centre in the north-east. The UK national strike of social workers (winter 1978-1979) led to coalitions with trades union members in other struggles. Meetings and rallies in London (London-Edinburgh Weekend Return Group, 1980) led in 1981 to the establishment of the journal Critical Social Policy. Expansion ceased - rearguard action was needed. For many, involvement in campaigns around health and welfare continued and expanded; for others it began.

\section{The present situation}

Planned changes to health provision continue (Department of Health, 2008; Socialist Health Association, 2008 www.sochealth.co.uk/news/NHSReform.htm ) and the division of local authority social work departments into children's trusts and adult social care will soon be completed. However, notwithstanding the rhetoric of integrated services for children, practice in the movement towards integration is uneven (C. Taylor, personal communication, 2007). Practitioners in health, mental health and social work still struggle with very similar dilemmas in work with patients and service users as did the author and colleagues in mental health settings earlier in their careers (Pearson, 1975) in relation to balancing rights of patients, service users and their and others' rights to 
protection - see, for example, Anderson et al (2004) on issues for mental health nurses working with young people who self-harm; Humphreys (1999) on some of the statutory social work responses with mothers who endure domestic violence.

Currently, an instrumental rationality characterises practice in health, mental health and social work. There are many de-motivated practitioners in these settings and many managers who are disconnected from any sense of the remit of services being to meet need and to support and protect (Davies, 2005). Workplace cultures in health, mental health and social work emphasise meeting delivery and performance targets and a 'tickbox culture’ prevails (Coffey et al, 2004; Kirkham, 2004 www.radmid.demon.co.uk/htm ). Exploring the inter-connected political and personal meanings of their work is impossible for many health and social work professionals; often the focus in supervision sessions is scrutiny of performance against predetermined standards, rather than consideration of needs or processes in developing relationships with patients and service users (Taylor, 2000 www.radmid.demon.co/megtaylor.htm ).

Davies (2005) notes the difficulties in maintaining a commitment to change in the current climate of targets and managerialism, a climate which is lived reality for so many health, mental health and social work professionals. In addition, many health and social work academic staff who currently undertake research and lecture to pre-qualifying professional students do not have the 'lived experience' of campaigning and political action in relation to health and social work services, or in other settings such as trades unions. Knowledge about the cross-fertilisation of activisms in the 1970s and the 
connections made between issues and campaigns in health, mental health and social work is being lost.

Hegemonic discourses and praxes appear immoveable, but dissatisfaction with the status quo can act as a disinhibiting factor. While ongoing changes in health, mental health and social work services to children and adults mean that the immediate future is difficult to read, there are ways to move forward, even if not at the pace of the 1970s. Giving voice to the views of many in social work (and also in health), Jones et al (2004) state:

'If it is the widening gap between promise and reality that breeds much of the current anger and frustration amongst social workers, it is also the awareness that social work could be much more than it is at present that leads many of us to hang in there.' (Jones et al, 2004 www.liv.ac.uk/sspSocialWorkManifesto.html )

\section{Seeking conditions: theory and praxis}

Many working in health and social work education (Cox and Hardwick, 2002; Jones, 1996; McKeown et al, 1998) believe that patients, service users and their carers deserve the best educated health and social work professionals who can understand and analyse patients', users' and carers' personal issues and also their circumstances as members of society: that is, consider the inter-relationships between personal, societal and political issues and the implications of all of this for their professional practice with patients and service users. Echoing the critique of the Case Con Manifesto in lamenting loss of 
specialist knowledge, Howe (1996) comments perceptively on the lack of frameworks which would facilitate an in-depth exploration of the emotions and material circumstances of service users and carers and the political and theoretical understandings which workers bring to bear on them:

'Clients are not located within the context of an ordered narrative; their story is not framed within a theoretical perspective whose principles govern what is said and done...there is no accumulated wisdom because there are no psychological or sociological frameworks in which to order and store it.' (Howe, 1996: 90-91).

Two theoretical perspectives which could be significant in developing a more radical praxis in health, mental health and social work now are explored. These are the critical theory of the Frankfurt School and psycho-social theory.

\section{Critical theory}

The Frankfurt School of critical theory builds upon the intellectual contributions of (among others) Marx and Freud. Like other feminists, the author has some reservations about the project of modernity and its metanarratives, including those of critical theory (Benhabib, 1992; Meehan, 1995). However, there is no space here for engaging in complex debates which are addressed comprehensively elsewhere: for example, Benhabib (1986). The relevance of critical theory for the education of health and social work professionals is the focus. 
Critical theory as developed within the Frankfurt School facilitates a vigorous, critical engagement with the social world (Horkheimer, 1993). According to Geuss (1981), critical theory is inherently emancipatory, has cognitive content, is self-conscious and self-critical. Calhoun describes the endeavour to:

'...distinguish critical theory from the sort of "traditional theory" that accepted the selfdefinitions of the familiar and failed to look more deeply at how the categories of our consciousness were shaped and how they in turn constituted both the world we saw, and what we took to be possible...the idea of critical theory as a distinctive project, and a project that would distinctively combine traditionally abstract and universal philosophy with historically concrete and empirical knowledge of the social world...' (Calhoun. 2000: 515).

Writings of the Frankfurt School from Horkheimer through to Habermas are characterised by commitment and concern to make theory ‘work' for society; the point of theory being to respond to political needs and move society in one social direction rather than another: 'a theory of society conceived with a practical intention' (Habermas, 1973: 1). Whilst critical theory is criticised for 'metanarratives of emancipation', Rorty (1995) comments that there is no sense of "we" and what "we can do to improve society" in the work of such critics (Cox and Hardwick, 2002).

Critical theory's political commitment to the possibilities of a freer, more inclusive society means that it can be applied to examine and critique the limitations, as outlined 
above, in societal structures and in current health, mental health and social work policy and practice. Critical theory's engagement with the social world enables professionals to question and challenge, creating new emancipatory discourses and moving towards: '...the development of new forms of living' (Beck, 1992: 235).

\section{Psycho-social theory}

The second theory examined here for relevance in the education of health and social work professionals is psycho-social theory, which builds upon the work of Freud and Klein. Again, many criticisms are made of psycho-social theory, including the apparent disregard by some proponents of issues of structural and social power (Wolf, 1992) and the apparently deterministic emphasis in some of Klein’s theorising: see, for example, Sayers (1987).

According to Miller et al:

'A psycho-social approach is one which draws upon both critical theory and psychoanalysis......[it] is concerned to understand the interaction between psyche and society, that is, their mutual influencing, using an approach which eschews both psychological and sociological reductionism.' (Miller et al, 2008).

For Froggett (2002) psycho-social theory can be applied across four linked domains: the intra-psychic; the social; the institutional and the societal - and thus used to analyse and 
understand both the personal and social worlds. These inter-connections and parallel structures between personal and social worlds are explained by Miller et al:

'..[it] recognises that both psyche and society have their own rules of structure formation. For the psyche ....it includes for example the mechanisms of splitting, projection, repression, denial, integration and reparation that produce dynamic patterns of internal relations between different parts of the personality. For society such rules of structure formation generate, for example, relations of class, gender and race, as well as relations between status groups and those between economy, state and civil society.' (Miller et al, 2008).

Acknowledging the influences of the intra-psychic, the social, the institutional and the societal through the application of psycho-social theory would engender in-depth knowledge of patients' and service users' emotional, social and material circumstances: see for example, Hoggett (2000); Searing (2003); Watkins (2001). This would counteract much of the personal, social and political de-legitimising of the experiences of patients, service users and carers, particularly for those suffering with unhappiness, depression or mental ill-health and for those caring for those who do. Taken together and applied to understanding both the social world and personal feelings, critical theory and psychosocial theory complement one another and can make connections for health and social work professionals in their relationships and work with patients, service users and carers: professional education for mental health nurses is already moving in this direction (NMC, 2004: 24). 


\section{Developing conditions: theory, politics and praxis}

Clem Attlee’s words (1920) about social workers being certain to be agitators, because of their knowledge of conditions of inequality, became reality for many in social work in the 1970s, just as they were for workers in health and mental health settings (Widgery, 1979). While Attlee may have approved of this position, there had been previous concerns expressed that social workers would become contaminated by their work with disadvantaged groups and end up seeing the world from the viewpoint of those who are oppressed; see Bosanquet (1916).

The potential for workers in health, mental health and social work settings to understand and develop analyses of the personal, social and societal situations of their patients, service users and carers, exists now much as it did when Attlee and Bosanquet made their observations; Marx’s thinking about people as social beings with their consciousness forged by social relationships (Lefebvre, 1971) is also relevant here.

Following from Morgan’s (1989) insistence on the need to see connections and establish alliances, making links with others needs to become a core endeavour in developing more radical discourses and praxes in health, mental health and social work. One example of success through the building of alliances to maintain or improve health provision is the National Abortion Campaign (NAC) in the UK, which, as noted above - see Connections and activisms in action - was supported by many working in health, mental health and social work; and which campaigned in defence of the 1967 Abortion Act. In 1979 NAC 
opposed the private member’s bill, brought by Corrie which sought to limit women’s access to abortion by reducing the upper time limit. The success of NAC in that campaign is thought to be due in part to the strong partnerships built with trades unions and MPs (Charles, 2000; Lovenduski, 1986). More recent health-related examples of the value of building links are noted by McKeown (2008).

Expertise among social workers in making links have been more limited, although as noted above, throughout the course of the social workers' strike (1978-1979) coalitions with other trades unions were made. The author and a number of social workers active in NALGO in the early 1980s in a city where 'riots' were deemed to have occurred (Benyon and Solomos 1987; Gilroy, 1987); volunteered to be available on a Saturday afternoon rota, to drive the partners, children and families of those who had been arrested, on visits to where they were being held on remand. There are other former and current social workers who have had, or who have, involvement in supporting or allying with members of communities outwith their statutory brief. Later, when awareness of the prevalence of child sexual abuse was becoming widespread and reflecting Firestone’s (1979) assertions, there were calls by activist practitioners to build alliances with survivors of abuse and their supporters, see, for example: Armstrong (1996); Cox, Kershaw and Trotter (2000b); Taylor-Browne (1997).

Alliances of patients and service users troubled by mental illness and their carers are being referred to as 'new social movements' (Hopkins et al, 2007), although the adjective 'new' is disputed by some (Crossley, 2002). Practitioners working in health and mental 
health are developing stronger alliances with service users and their carers (McKeown, 2008). There is thus more current expertise amongst health and mental health professionals of making connections within, and outside of, health and mental health settings, which would benefit social workers who have not had the experiences described just above. However, it is important to be aware that for many service users, patients and carers, trust and credibility will need to be earned and established by professionals in health, mental health and social work before partnerships can be secured and maintained (Hopkins et al, 2007; Wills and Simms, 2004.)

In a large-scale study of social service departments in the north of England, Coffey, Dugdill and Tattersall (2004) note respondents reporting that to improve job satisfaction they wanted either increased staffing, or lower workload levels, so that sufficient time could be allocated to the real needs of service users. Much the same findings appear in a smaller-scale study by Jones (2001) and in feedback from the social workers who contributed to research by Care Services Improvement Partnershop and the National Institute of Mental Health in England (CSIP and NIMHE, 2006). Research with service users and carers about their views of social work: for example, Shaping Our Lives and Beresford, (2007); Stanley and Cox, (2007) emphasises need for communication, time spent together, and understanding and knowledge about user and carer concerns and social circumstances. Feedback from service users of mental health services and their carers is strongly similar (Department of Health, 2006). The author observes that these findings are supported by the responses of pre-qualifying students to such studies: would-be health and social work professionals are well-aware of the need to engage with 
patients, service users and carers as people, rather than as targets to be processed (Davies, 2005). Here are opportunities to establish and construct partnerships at an early stage, both during professional education, and with and between the professions of health, mental health and social work, and with patients and service users, around what patients and users want. Scambler's (1998) work addressing moral responsibilities and the establishment of alliances of social critics and activists has much to say to professionals in health, mental health and social work about the importance of doing this: see also Cox and Hardwick (2002).

In their evaluation of the contribution of Sedgwick's (who also advocated constructing alliances) 1982 work for mental health movements, Cresswell and Spandler (2008) observe that the wider left have not yet fully engaged with the political dimensions of mental health. This is also true in relation to social work, particularly child sexual abuse (Cox, Kershaw and Trotter, 2000a; Crompton 1992; Kelly and IL, 2008 www.newstatesman.com/uk-politics/2008/07women-violence-abuse.htm ) where the messengers are blamed (Taylor-Browne, 1997), rather than the messages being heard. Many local councillors, like many MPs, now do not come from traditions of activisms, do not hold values that they are accountable for public services and do not support a role for the trades unions in service delivery (see also Kettle, 2007; McKeown, 2008). Addressing the left's lack of engagement on these two issues is a longer-term project in communication (Alinsky, 1972: xx), requiring a different focus and emphasis from that needed in establishing trust with patients, service users and carers. 


\section{Seeing and making connections}

Links between personal troubles and social issues and the impact of personal troubles on families, communities and societies, are more widely understood than previously although regrettably, such understanding is not yet total: for example, James (2005); Keedwell (2008); Smail (1987, 2005). There is also more widespread awareness of the links between people’s positions in society and their physical health - or lack of it (Marmot, 2004; Wilkinson, 1996; Williamson, 2000). Such links are also acknowledged occasionally in mainstream media. UK TV station Channel 4 has produced three series of ‘The Secret Millionaire’ in which each week a self-made millionaire goes 'undercover' as a volunteer, working with community-based projects in severely deprived areas of the UK. At the end of each programme they give large amounts of their own money to the projects or individuals that they believe most need it, most deserve it, or who will use it to best advantage. While several aspects of this concept and the programme are open to criticism, in the two final weeks of series three each millionaire spoke openly about their new-found recognition that circumstances can cause insuperable difficulties, rather than (as they previously thought) individuals being entirely responsible for their own plight. The author is paraphrasing these remarks from very recent memory; however, analagous interviews with the two may be found on the programme website (www.channel4.com/culture/microsites/S/secret_millionaire/millionaires/kavitainterview.html and www.channel4.com/culture/microsites/S/secret_millionaire/millionaires/nickinterview.html ). The author is not arguing that this programme will lead to revised thinking about health and welfare provision in the UK; only that it shows that deeply-held 
attitudes can be changed - the two millionaires and perhaps some of the viewers who listened to them - and that points made by Attlee and Bosanquet still have validity.

The first two examples in the paragraph above do not demonstrate a swing back to the radical 1970s: what they do demonstrate is that some strands of knowledge have survived which influence, however minimally, present understandings. Other influences from, and connections with, more radical times can be discerned. Examples include: the Association of Radical Midwives’ website (Kirkham, 2004; Taylor 2000); recent acknowledgement of the contribution of Radical Health Visitors (Billingham et al, 1996); the Manifesto for an Engaged Social Work Practice (Jones et al, 2004). Chesler's Women and Madness (1973) has been re-issued (2005). These perhaps constitute identifiable 'straws in the wind' or 'connections'; not individually very strong but which, if brought together, have the potential for assisting in the reclaiming or rebuilding aspects of radical practice.

\section{Conclusion: conditions, connections and 'connectivity'.}

As noted above (Seeking conditions: theory and praxis), critical theory of the Frankfurt School and psycho-social theory both provide valuable frameworks (Howe, 1996), in which to develop analyses and understandings of patients', service users' and carers' personal, social and societal issues. The application of both critical theory and psychosocial theory in professional education in health, mental health and social work, creates possibilities of a unity of theory and practice, leading onto more knowledgeable and 
critically engaged forms of praxis in relationships and work with patients, service users and carers:

'The issue was not just a use of theory in the service of political ends - a version of instrumental reason - but, rather, the development of a broader sense of political practice as the constitution of ways of living together that enabled the full realisation of human potential.' (Calhoun, 2000: 526).

It is necessary to work within health, mental health and social work 'systems' (Alinsky, 1972: xix) to effect changes and, in addition, to establish alliances within and beyond those systems with others of like mind and understanding (McKeown, 2008; Scambler, 1998). In 1980, Bailey and Brake had emphasised the importance of applying analytical frameworks and of building alliances, arguing that:

'It is essential to work through people's feelings of depression, aggression or despair with the aims of helping them at both an individual and a collective level. This means starting with their definition of the situation and their values, and then trying to extend these into a wider understanding of self and society...prepare the person to become whole enough so that they can engage in struggle with their situation individually and then, perhaps, collectively...developing through practice ways of working which will give support to social change and which will genuinely affect the lives of consumers.' (Bailey and Brake, 1980: 23-24). 
While this was written for one professional group practising in very different times, it is equally applicable to all working in health, mental health and social work today.

This exploration began with memories, reflections and analyses, moving into an ensuing search for what could be (Habermas, 1973); for conditions needed to develop more radical ways of thinking and working and for connections to improve discourses and praxes, patient, service user and carer relationships and service delivery. For the movement from 'roots’ to 'routes’ (as originally conceptualised by Gilroy; cited in McLeod, 2000: 231), the solutions of theory and action, knowledge, analyses and praxis are found to be as relevant to health, mental health and social work as they have ever been.

WORDCOUNT: 5, 305 - including 200 word abstract. DATE: 22.08.08.

\title{
REFERENCES
}

Adlam D, Henriques J, Rose N, Salfield A, Venn C, Walkerdine V (Editorial Collective) (1975-1982) Ideology and Consciousness. Publication Distribution Co-Op: London.

\author{
Alinsky S (1972) Rules for Radicals: A Pragmatic Primer for Realistic Radicals. \\ Vintage: New York.
}

Anderson M, Woodward L, Armstrong M (2004). Self harm in young people: a perspective for mental health nursing care. International Nursing Review 51: 4 222-228. 
Armstrong L (1996) Rocking the Cradle of Sexual Politics: What Happened When Women Said Incest. The Women's Press: London.

Bailey M, Brake R (eds) (1975) Radical Social Work. Edward Arnold: London.

Bailey M, Brake R (eds) (1980) Radical Social Work and Practice. Edward Arnold: London.

Banyard VL, Williams LM (1999). Memories for child sexual abuse and mental health func tioning: findings on a sample of women and implications for future research. In: Williams LM, Banyard VL (eds). Trauma and Memory. Sage: Thousand Oaks, California. pp 115-125.

Beck U (1992) Risk Society: Towards a New Modernity. Sage: London.

Benhabib S (1986) Critique, Norm and Utopia: A Study of the Foundations of Critical Theory. Columbia University Press: New York.

Benhabib S (1992) Situating the Self: Gender, Community and Postmodernism in Contemporary Ethics. Polity Press: Cambridge.

Benyon J, Solomos J (eds) (1987) The Roots of Urban Unrest. Pergamon Press: Oxford. 
Bifulco A, Moran P (1998) Wednesday's Child: Research into Women's Experience of Neglect and Abuse in Childhood and Adult Depression. Routledge: London.

Billingham K, Morrell J, Billingham C (1996). Reflections on the history of health visiting. British Journal of Nursing 1: 7 386-392.

Bosanquet R (1916). The philososphy of casework. Charity Organisation Review 39: 117-138.

Briere J, Runtz M (1986). Suicidal thoughts and behaviors in former sexual abuse victims. Canadian Journal of Behavioral Science 18: 4 413-423.

Briere J, Runtz M (1987). Post sexual abuse trauma: data and implications for clinical practice. Journal of Interpersonal Violence 2: 4 367-379.

Brown P (1973) Radical Psychology. Harper Colophon: New York.

Brown P (1974) Towards a Marxist Psychology. Harper Colophon: New York.

Calhoun C (2000). Social theory and the public sphere. In: Turner BS (ed). The Blackwell Companion to Social Theory 2nd ed. Blackwell Publishers: Oxford. 
Care Services Improvement Partnership (CSIP) and National Institute of Mental Health in England (NIMHE) (2006). Report of responses to discussion. London: NIMHE.

Case Con Collective (1975). Appendix: Case Con Manifesto. In: Bailey R, Brake M (eds). Radical Social Work. Edward Arnold: London. pp 144-147.

Charles N (2000) Feminism, The State and Social Policy. Macmillan Press Ltd.: Houndmills, Basingstoke.

Chesler P (1973) Women and Madness. Avon Books: New York.

Chesler P (2005) Women and Madness. Palgrave Macmillan: Basingstoke.

Cockburn C (1977) The Local State: Management of Cities and People. Pluto Press: London.

Coffey M, Dugdill L, Tattersall A (2004). Stress in social services: mental well-being, constraints and job satisfaction. British Journal of Social Work 34: 5 735-746.

Corrigan P, Leonard P (1978) Social Work Practice under Capitalism: a Marxist Approach. Macmillan: Basingstoke. 
Cox P (1993). 'Professional survival' - a double jeopardy: some implications for training, education and practice. In: Ferguson H, Gilligan R, Torode R (eds). Surviving Childhood Adversity: Issues for Policy and Practice. Social Studies Press: Dublin. pp 134-139.

Cox P, Hardwick L (2002). Research and critical theory: their contribution to social work education and practice. Social Work Education 21: 1 35-47.

Cox P, Kershaw S, Trotter J (eds) (2000a) Child Sexual Assault: Feminist Perspectives. Palgrave: Basingstoke.

Cox P, Kershaw S, Trotter J (2000b). Conclusion. In: Cox P, Kershaw S, Trotter J (eds). Child Sexual Assault: Feminist Perspectives. Palgrave: Basingstoke, Hampshire. pp 178181.

Cresswell P, Spandler H (2008). Psychopolitics: Peter Sedgwick's legacy for mental health movements. Unpublished Paper. Alternative Movements and Popular Protest, 13th International Social Movements Conference; Manchester, 17-19 March.

Crompton I (1992) Child Sexual Abuse: Politics, Ideology and Social Work Practice. University of Warwick: Warwick.

Crossley N (2002) Making Sense of Social Movements. Open University Press: Buckingham. 
Davies L (2005). Authentic practice works. Professional Social Work, December 2005.

Department of Health (2006) From values to action: the chief nursing officer's review of mental health nursing. London: Department of Health.

Department of Health (2008) High quality care for all: NHS next stage review. London: Department of Health.

Department of Health and Social Security (1976) Priorities for health and personal social services in England. London: Department of Health and Social Security.

Doyal L, with Pennell I (1979) The Political Economy of Health. Pluto Press: London.

Ehrenreich B, English D (1974) Witches, Midwives and Nurses: A History of Women Healers. Writers and Readers Publishing Co.: London.

Ehrenreich B, English D (1979) For Her Own Good: 150 Years of the Experts' Advice to Women. Pluto Press: London.

Firestone S (1979) The Dialectic of Sex: A Case for Feminist Revolution 2nd ed. The Women’s Press: London. 
Froggett L (2002) Love Hate and Welfare: Psychosocial approaches to policy and practice. Policy Press: Bristol.

Geuss R (1981) The Idea of a Critical Theory: Habermas and the Frankfurt School. Cambridge: Cambridge.

Gilroy P (1987) 'There Ain't No Black in the Union Jack': The Cultural Politics of Race and Nation. Routledge: London.

Habermas J (1973) Theory and Practice. Beacon Press: Boston.

Henriques J, Hollway W, Urwin C, Venn C, Walkerdine V (1984) Changing the Subject: Psychology, Social Regulation and Subjectitivity. Methuen and Co. Ltd: London.

Hoggett P (2000) Emotional Life and the Politics of Welfare. Macmillan Press: Basingstoke, Hampshire.

Hopkins R, Cox P, Downe S, McKeown M (2007). Making sense of health and social care service user participation in a university setting: the relevance of social movement theory. Unpublished paper. Alternative Futures \& Popular Protest. 12th International Social Movements Conference; Manchester, 2nd-4th April. 
Horkheimer M (1993) Between Philosophy and Social Science: Selected Early

Writings(tr. Hunter.G.F., M. S. Kramer \& John Turgy ). MIT Press: Cambridge, MA.

Howe D (1996). Surface and depth in social work practice. In: Parton N (ed). Social Theory, Social Change and Social Work. Routledge: London.

Humphreys C (1999). Avoidance and confrontation: the practice of social workers in relation to domestic violence and child abuse. Child \& Family Social Work 4: 177 - 87.

James O (22 October 2005). Think again: new research on schizophrenia suggests that the drugs won't always work. The Guardian.

Jones C (1996). Anti-intellectualism and the peculiarities of British social work education. In: Parton N (ed). Social Theory, Social Change and Social Work. Routledge: London.

Jones C (2001). Voices from the front line: state social workers and new Labour. British Journal of Social Work 31: 4 547-562.

Jones C, Ferguson I, Lavalette M, Penketh L, (2004), Social work and social justice: a manifesto for a new engaged practice, Liverpool, University of Liverpool, www.liv.ac.uk/sspSocialWorkManifesto.html. 
Keedwell P (27 February 2008). Upsides of being down. The Guardian (Society).

Kempe HC, Silverman F, Steele B, Droegmuller W, Silver H (1962). The battered baby syndrome. Journal of the American Medical Association 181: 4-11.

Kettle M (26 January 2008). Hain’s departure epitomises the eclipse of 60s idealism. The Guardian.

Lefebvre H (1971) The Sociology of Marx. Allen Lane/The Penguin Press: London.

London-Edinburgh Weekend Return Group (1980) In and Against the State. Pluto Press: London.

Lovenduski J (1986). Parliament, pressure groups, networks and the women's movement: the politics of abortion law reform in Britain (1967-1983). In: Lovenduski J, Outshoorn J (eds). The New Politics of Abortion. Sage: London. pp 49-66.

Mannheim K. (1952) 'The Problem of Generations.' Essays on the Sociology of Knowledge. London: Routledge and Kegan Paul, pp 276-323.

Marmot M (2004) Status Syndrome:How Your Social Standing Directly Affects Your Health and Life Expectancy. Bloomsbury: London. 
McKeown M (2008). Alliances in action: opportunities and threats to solidarity between workers and service users in health and social care disputes. Unpublished paper. Alternative Futures and Popular Protest. 13th International Social Movements Conference; Manchester, March 17-19.

McKeown M, McCann G, Bentall R (1998). Time for action - a new system for training mental health practitioners. Mental Health Care 1: 5 158-158.

McLeod J (2000) Beginning Postcolonialism. Manchester University Press: Manchester.

Meehan J (ed) (1995) Feminists Read Habermas: Gendering the Subject of Discourse. Routledge: New York.

Miller C, Hoggett P, Mayo M (2008). Psycho-social perspectives in policy and professional pactice research. In: Cox P, Geisen T, Green R (eds). Qualitative Research and Social Change: European Contexts. Palgrave: Basingstoke.

Morgan R (1989) 'The Demon Lover': On the Sexuality of Terrorism. Methuen: London.

Nursing and Midwifery Council (2004) Standards of proficiency for pre-registration nursing education. London: Nursing and Midwifery Council. 
Parton N (1996). Social theory, social change and social work: an introduction. In: Parton N (ed). Social Theory, Social Change and Social Work. Routledge: London.

Pearson G (1975). Making social workers: bad promises and good omens. In: Bailey R, Brake M (eds). Radical Social Work. Edward Arnold: London. pp 13-45.

Radical Statistics Health Group (1976) Whose priorities? A critique of priorities for health and personal social services' statistics in england. London: Radical Statistics.

Radical Statistics Health Group. (1978). A critique of priorities for health and personal social services statistics in England. International Journal of Health Services 8: 367-400.

Rorty R (1995). Habermas and Lyotard. In: Giddens A, Held D, Hubert D, Seymour D, Thompson J (eds). The Polity Reader in Social Theory. Polity Press: Cambridge. pp 160171.

Salter A (1988) Treating Child Sex Offenders and Victims: A Practical Guide. Sage: Newbury Park, CA.

Sayers J (1987). Melanie Klein, psychoanalysis and feminism. Feminist Review 25: Spring 23-37. 
Scambler G (1998). Medical sociology and modernity: reflections on the public sphere and the roles of intellectuals and social critics. In: Scambler G, Higgs P (eds). Modernity, Medicine and Health: Medical Sociology Towards 2000. Routledge: London.

Searing H (2003). The continuing relevance of casework ideas to long-term child protection work. Child \& Family Social Work 8: 4 311-320.

Sedgwick P (1982) Psychopolitics. Pluto Press: London.

Seebohm Committee (1968) Report by the committee on local authority and allied social services. London: HMSO.

Shaping Our Lives, Beresford P. The roles and tasks of social workers: report of service user consultation for the England review, 28 february 2007. London: GSCC, (2007).

Simpkin M (1979) Trapped Within Welfare. Macmillan: London.

Skeggs B (1997) Formations of Class and Gender. Sage: London.

Smail D (1987) Taking Care: An Alternative to Therapy. J.M.Dent and Sons: London.

Smail D (2005) Power, Interest and Psychology: Elements of a Social Materialist Understanding for Distress. PCCS Books: Herefordshire. 
Stanley N, Cox P. (2007) Knowledge review for SCIE: parental mental health and child welfare: reviews of policy and professional education. Preston: University of Central Lancashire,

Taylor C, (2007) Personal communication.

Taylor-Browne J (1997). Obfuscating child sexual abuse 1: the identification of social problems. Child Abuse Review 6: 1 4-10.

Walkerdine V (1997) Daddy's Girl: Young Girls and Popular Culture. Macmillan: Basingstoke, Hampshire.

Watkins P (2001) Mental Health Nursing: The Art of Compassionate Care. ButterworthHeinemann: Edinburgh.

Widgery D (1979) Health in Danger:Crisis in the National Health Service. Macmillan: Basingstoke.

Wilkinson R (1996) Unhealthy Societies: The Afflictions of Inequality. Routledge: London. 
Williamson E (2000) Domestic Violence and Health: The Response of the Medical Profession. Policy Press: Bristol.

Wills J, Simms J (2004). Building reciprocal community unionism. Capital and Class 82 : 59-84.

Wilson E (1980) Only Halfway to Paradise: Women in Postwar Britain 1945-1968. Social Science Paperbacks: London.

Wise S (1988) Doing Feminist Social Work: An Annotated Bibliography and An Introductory Essay. University of Manchester Press: Manchester.

Wolf S (1992). Comment. In: Gutmann A (ed). Multiculturalism and 'The Politics of Recognition’. Princeton University Press: Princeton NJ.

Wyatt GJ, Powell GE (eds) (1988) Lasting Effects of Child Sexual Abuse. Sage: Newbury Park, California. 